\title{
Referaten
}

\section{Goed voorbeeld doet goed volgen}

Custers EJFM, Regehr G, McCulloch W, Peniston C, Reznick $R$. The effect of modeling on learning a simple surgical procedure: see one, do one or see many, do one? Advances in Health Sciences Education 1999,4(2):123-43.

Dit artikel beschrijft praktisch en relevant onderzoek voor degenen die vaardigheidsonderwijs geven en organiseren. Custers doet verslag, als deel van een internationaal keurkorps auteurs, van onderzoek naar het effect van het onderdeel 'voordoen' in vaardigheidstraining. In een training van een eenvoudige chirurgische ingreep (de excisie van een huidlaesie en het sluiten van de wond die daardoor ontstaan is) zijn drie condities vergeleken. Tweedejaars studenten kregen een beschrijving van de vaardigheid op papier. Vervolgens kregen drie subgroepen géén, éen of vier video-voorbeelden van de vaardigheid te zien, verricht door ervaren chirurgen. Ten slotte hebben alle studenten de vaardigheid vier keer verricht. Deze resultaten zijn geregistreerd met een checklist, een globale beoordeling en registratie van de benodigde tijd.

Studenten die één of vier voorbeelden hadden gezien, boekten vergelijkbare resultaten. Deze beide groepen studenten presteerden beter dan degenen die geen voorbeeld(en) gezien hadden.

J. van Dalen, Maastricht

\section{Hoe effectief is pgo?}

Colliver JA. Effectiveness of problem-based learning curricula: research and theory. Acad Med 2000; 75: 259-66.

Discussies over nut en noodzaak van probleemgestuurd onderwijs (pgo) zijn niet alleen in Nederland actueel en in het kader van die discussie is het artikel van Colliver een aanwinst. Hij bespreekt het vergelijkend onder- zoek dat gedaan is naar de effecten van pgo en traditioneel onderwijs (niet-pgo) op kennis en klinische vaardigheden. Daarvoor geeft hij een samenvatting van drie overzichtsartikelen uit 1993 die de discussie en het onderzoek uit de periode vóór 1992 beschrijven en bespreekt hij de studies die tussen 1992 en 1999 zijn gepubliceerd. Voor de vergelijking van de resultaten gebruikt hij het gestandaardiseerde gemiddelde verschil (d), dat bij een optimaal effect uit kan komen op d=2.00. Het afkappunt tussen een wel en niet acceptabel effect kiest Colliver bij $d=1.00$. Voor artikelen waarin $d$ niet gegeven wordt, berekent hij hem alsnog.

Sinds 1992 zijn acht studies verschenen; voor drie daarvan zijn studenten gerandomiseerd over pgo en niet-pgo, voor vier studies niet. Bij veel studies worden kritische kanttekeningen geplaatst rond methodologie en/of conclusies. Samenvattend varieert d voor het effect van pgo op kennis en vaardigheden ten opzichte van niet-pgo van -.33 tot .80 . In gerandomiseerd onderzoek is d kleiner dan in niet-gerandomiseerd onderzoek. Dat verschil is goed verklaarbaar met de invloed van zelfselectie (studenten kiezen bewust voor pgo) en het gebruik van uitkomstmaten die direct gerelateerd zijn aan onderwijsactiviteiten binnen het pgo. Naar aanleiding van deze resultaten gaat Colliver in zijn discussie in op de wankele theoretische basis onder twee uitgangspunten van pgo - reactivering van voorkennis en het belang van context - en pleit voor meer fundamenteel onderzoek op dat gebied.

Vooralsnog is er geen overtuigend wetenschappelijk bewijs dat pgo ten opzichte van niet-pgo winst oplevert wat betreft het verwerven van kennis en vaardigheden.

J. Pols, Groningen 